\title{
Biometry and oil contents of Acrocomia aculeata fruits from the Cerrados and Pantanal biomes in Mato Grosso do Sul, Brazil
}

\author{
Gabrielly Ciconini $^{\mathrm{a}, *}$, S.P. Favaro ${ }^{\mathrm{a}, 1}$, R. Roscoe $^{\mathrm{b}}$, C.H.B. Miranda ${ }^{\mathrm{c}}$, C.F. Tapeti ${ }^{\mathrm{a}}$, M.A.M. Miyahira ${ }^{\mathrm{a}}$,

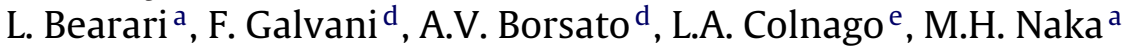 \\ a Catholic University Dom Bosco, P.O Box 100, 79117-900 Campo Grande, MS, Brazil \\ ${ }^{\mathrm{b}}$ MS Research Foundation, Estrada Usina, 79150-000 Maracaju, MS, Brazil \\ c Embrapa Agroenergy, PqEB W3 N, 70770-901 Brasilia, DF, Brazil \\ d Embrapa Pantanal, P.O. Box 109, 79320-900 Corumba, MS, Brazil \\ e Embrapa Instrumentation, 15 de Novembro 1452, 13560-970 Sao Carlos, SP, Brazil
}

\section{A R T I C L E I N F O}

\section{Article history:}

Received 11 July 2012

Received in revised form

12 November 2012

Accepted 8 December 2012

\section{Keywords:}

Macauba palm

Mesocarp oil

Kernel oil

Oily fruits

Oil yield

Coproducts

\begin{abstract}
A B S T R A C T
Biometric features and oil contents of macauba (Acrocomia aculeata) palms natively growing in sites representatives of the Brazilian Cerrados (Campo Grande - CG, and Sao Gabriel do Oeste - SGO), and Pantanal (Corumba - CO, and Aquidauana - AQ) biomes were studied. The objective was to obtain data that could assist better planning for the exploitation of natural populations, and knowledge to help selection and breeding programs. Plant (spines presence; stem circumference; number and length of bunches) and fruits characteristics (fruits per bunch; size; mass; proportion of components - husk, pulp, shell and kernel; fruits moisture at ripening; pulp and kernel oil content) were measured from ten native palms from each site. There was variability in biometrics, biomass production potential and oil yield in the palms within each site and among the sites. No correlation was found between biometrics features and oil contents. On average, plants from CG showed better general productive characteristics than any other of the studied sites, but a large variability in fruits size. Palms from CO presented smaller fruits, but they were more homogeneous in size and with higher kernel oil contents. Fruits from SGO show bigger mass and size, but it did not result in higher fruit biomass production or oil yield. Although oil yields potential were almost half of what is usually measured in other areas of Brazil, results provided interesting data for a better planning to rational exploitation of native macauba groves in these areas. Variability within plants from all sites indicate that they could be a reserve of genetic materials for further development of cropping systems aiming production of oil and other useful products.
\end{abstract}

(C) 2012 Elsevier B.V. All rights reserved

\section{Introduction}

Acrocomia aculeata (macaw palm) is a species of native palm to tropical regions of the Americas. It occurs naturally from southern Mexico and the Caribbean south to Paraguay and northern Argentina. In Brazil, were it is widely distributed, is commonly known as macauba palm (Cetec, 1983), with high population concentrations in the biomes Cerrados and Pantanal (Cetec, 1983).

The Cerrados, the second largest Brazilian biome, is a savannahlike area, characterized by a long dry weather period and acid, nutrient-depleted soils (Klink and Machado, 2005). The Pantanal, on the other hand, encompasses South-America inner lowland

\footnotetext{
* Corresponding author.

E-mail address: gabyciconini@hotmail.com (G. Ciconini).

1 Present address: Embrapa Agroenergy, PqEB W3 N, 70770-901 Brasilia, DF, Brazil.
}

areas submitted to long flooding periods (Schessil, 1999). Macauba palm is found in both environments, which demonstrates its high adaptation capability.

Macauba palm can be used with different purposes. Leaves can be used for animal nutrition, fruits are used for human consumption (food) and the endocarp (shell) and the epicarp (husk) can be used as a biomass sources for different uses, such as coal or briquettes. In the Pantanal, fruit pulp flour is used to prepare ice creams, cakes and others edible products. In other areas of Brazil there is an incipient use of the oil for industrial purposes, such soap making (mainly kernel oil) and surface coating for ceramic production. In Paraguay there is a long traditional industry related to extract and export of kernel oil for several purposes (Poetsch et al., 2012).

Nowadays, there is an increasing interest on its high oil yield, second only to palm oil (Elaies guineenses). It may produce ten times more oil per hectare than soybeans (Roscoe et al., 2007). This is an essential feature to match requirements as a sustainable source to produce biofuels. In parallel, the oleic acid content of the pulp 
oil makes it highly desirable to increasing demands of the food industry. Also, it can be easily incorporated into agrosilvipastoral systems, adding to the sustainability of this productive chain.

As palm oil cultivated in the equatorial belt (Basiron, 2005), macauba has got two economically important kind of oils, stored in the fruit pulp and in its kernel. Pulp oil has an intense orange color and it is characterized by the presence of carotenoids and high concentration of oleic acid (Hiane et al., 2005; Ramos et al., 2007). Kernel oil has a transparent aspect with a predominance of oleic acid and lauric acid (Amaral et al., 2011; Hiane et al., 2005). Both oils can be used for different industrial purposes, such as cosmetics, pharmaceuticals, food and in biofuels production. Coproducts obtained after oil extraction can be used for animal nutrition as they have no antinutritional or toxic compounds, and cogeneration of energy.

A valuable feature of macauba palm is the variability in phenotypic characteristics. This may impact fruits productivity and oil characteristics. The State of Mato Grosso do Sul, in the western area of Brazil, in the center of South America, provides a good ground to study such variability, as it encompasses parts of both Cerrados and Pantanal biomes. Thus, the aim of this work was the evaluation of the diversity among native populations of macauba in these areas, specially related to fruits biometry, moisture and oil contents at maturity. Furthermore, the biomass, oil and coproducts production were estimated. Such knowledge is very important to predict the productive potential of native macauba's populations, aiming the selection of high oil yielding plants, to provide materials for selection and breeding programs for commercial crop exploitation.

\section{Materials and methods}

\subsection{Harvest}

Whole bunches of native macauba palms with mature fruits, identified by natural detachment of the first fruits, were harvested at random in four different sites within the State of Mato Grosso do Sul (MS). Two of these sites are part of the Cerrados biome, in Campo Grande (CG, latitude: S $20^{\circ} 25.510^{\prime}$, longitude: O $54^{\circ} 58.122^{\prime}$ ) and São Gabriel do Oeste (SGO, latitude: S $19^{\circ} 38.272^{\prime}$, longitude: W 54 22.099') municipalities. The other two sites are part of the Pantanal, in Corumba (CO, latitude: S $19^{\circ} 17.589$, longitude: W $57^{\circ} 64.217$ ) and Aquidauana (AQ latitude: S 20 32.634', longitude:
W $55^{\circ} 33.258^{\prime}$ ) municipalities. Overall sites location is presented in Fig. 1.

For measurements, ten native palms were selected at random in each site. Exception was SGO, where eight palms were sampled. Palms were selected from a standard grove, representative of the larger area. Palms were selected if they have bunches around $2.5 \mathrm{~m}$ height, which facilitate harvest and provides a tentative of standardization. It is not possible to assure that these palms have the same age, once their internodes height varied quite a lot.

Harvest and measurements made at the site were carried out from November 2010, to January 2011. Every plant location was determined using Global Positioning System (GPS).

\subsection{General aspects of the macauba palm}

From every selected palm in each site the following measures were annotated: presence of spines in the stems; circumference of the stem at breast height; number of bunches; number of fruits per bunch; length of bunch.

\subsection{Fruits biometry}

From every selected palm, the number of bunches was annotated and one bunch was harvested. All fruits in the bunch were counted and ten fruits were selected at random for further analysis, twice as much as recommended by Manfio et al. (2011) to determine biometrics features with 95\% confidence. Fruit mass and the masses of its components (epicarp - husk, mesorcarp pulp, endocarp - shell and kernel) were weighed using an analytical balance (Bel Engineering, Mark Serie). Vertical and horizontal diameters were measured using a digital caliper (Zaas Precision, $150 \mathrm{~mm}$ ).

Fruits were peeled and pulped manually using a stainless steel knife. Shell was broken to extract the kernels with the help of a small hammer.

\subsection{Pulp and kernel moisture and oil contents}

Pulp and kernel moisture was determined as described in AOAC (2005). Oil content was determined by nuclear magnetic resonance (NMR) low field (Spinlock Magnetic Resonance Solutions, SLK 100).

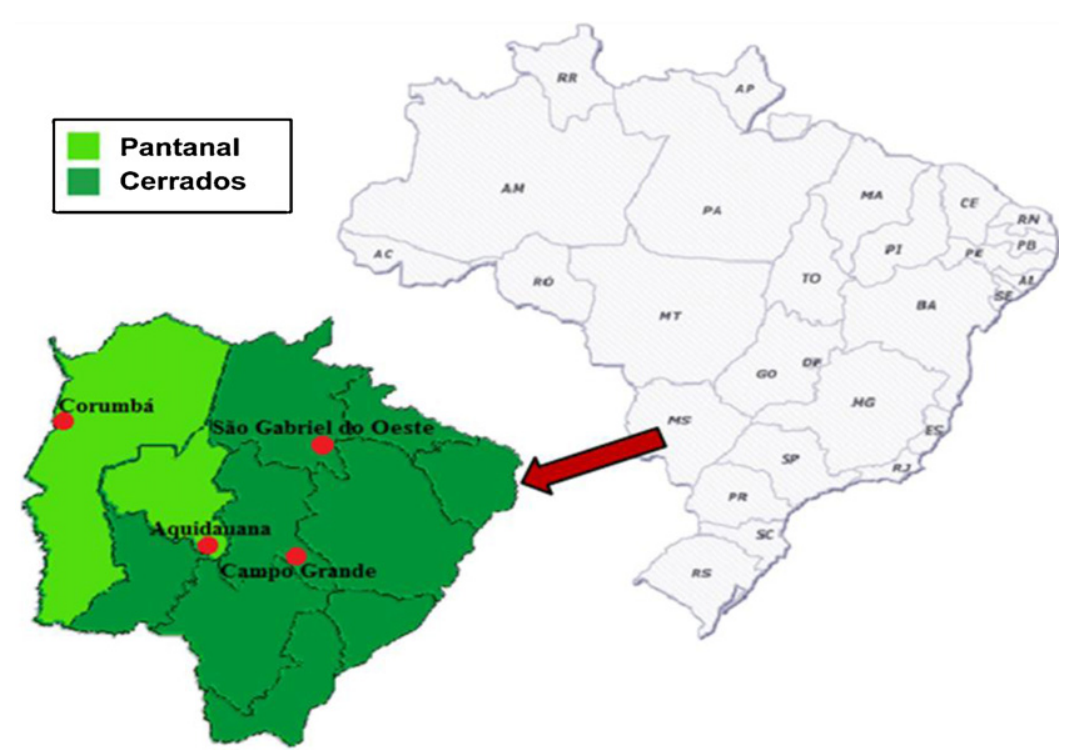

Fig. 1. Sites of harvest in the Cerrados and Pantanal biomes, Mato Grosso do Sul State (MS), Brazil. 


\subsection{Production estimations}

Total number of fruits per palm was calculated multiplying the number of fruits per bunch by the number of bunches per palm. Similarly, total mass of fruits per palm was obtained by the multiplication of total mass of fruits per bunch, in $\mathrm{kg}$, and the number of bunches per palm. Theoretical pulp oil yield was calculated using Eq. (1). The kernel oil yield was estimated similarly by replacing terms in Eq. (1) with kernel parameters. All values are in a wet basis.

$O Y=(T M F P \times P \times O C N P) \times 0.7$

where $O Y=$ pulp or kernel oil yield $(\mathrm{kg})$ per hectare; $T M F P=$ total mass of fruits $(\mathrm{kg})$ per palm; $P=$ pulp or kernel proportion to the entire fruit ( $g$ of pulp or $g$ of kernel/100 $g$ of fruit); $O C=$ pulp or kernel oil contents ( $\mathrm{g}$ of oil/100 g of pulp); $N P=$ number of palms per hectare; $0.7=$ oil extraction efficiency using mechanical processing.

\subsection{Experimental design}

Data were analyzed in a complete randomized design using ANOVA and the means were compared by Tukey test with $5 \%$ significance level. For comparison of biomes, data for the two sites encompassed in a given biome were considered as population replications. For comparison of sites, their overall data were considered, without effect of biomes. Comparisons within biomes were made using data for the two sites of that biome. Pearson correlations were performed at $5 \%$ significance level.

\section{Results and discussion}

Macauba palms present stems with different characteristics, such as with and without adhered petioles, or the presence or absence of spines in the internodes (Fig. 2). We found that around $30 \%$ of palms from CO and 70\% from AQ, both in the Pantanal, presented spines (data not shown). No spines were found in plants from the two Cerrados locations within the studied populations, although surely there are spiny plants in the Cerrados. The presence of spines may be determined by plants genetics and may also to be related to the palm age, as young palms are always spiny. In any form, spines are a nuisance to handle the palm, thus genotypes without spines or that loose them at early age are desirable to facilitate harvest and agronomic practices.

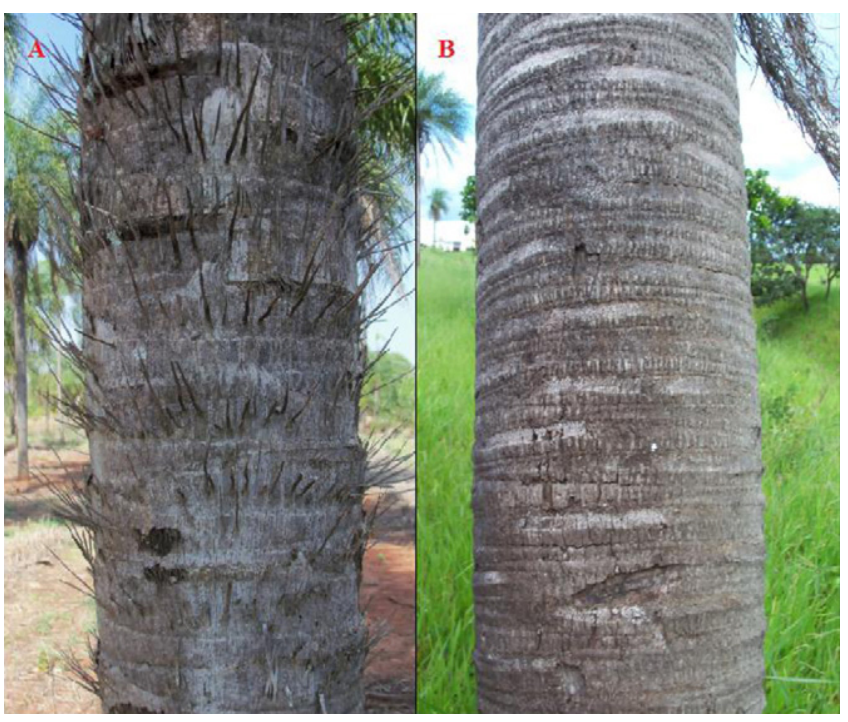

Fig. 2. Stems of macauba palm with (A) and without spines (B).
Palms from both biomes presented, on average, similar circumference of stems but there was significant differences $(p<0.05)$ for sites of harvest. The smallest and the largest circumferences were found, respectively, in AQ and CO, both in the Pantanal biome (Table 1). The average number of bunches per plant showed coefficient of variation as large as $64.9 \%$, indicating high variability within plants of all sites of both biomes. Although such variability eliminates differences $(p>0.05)$ for the effects of biomes, there was significant differences $(p<0.05)$ for sites, with plants from CG showing the largest number of bunches per plant, 5.3 on average, with one of them having 13 bunches. Plants from CG were also among those with longest bunches, compared to those from SGO and AQ. Plants from CO showed shorter lengths. The maximal length of the bunch $(99 \mathrm{~cm})$ was observed in a palm from AQ, while the largest total mass of the fruits $(9.3 \mathrm{~kg})$ was found in a bunch from SGO.

Overall, this variability in the plants phenotypic characteristics suggest that although macauba palm grows well in the wild in any situation, there is strong effect of the local environment, which may be related to moisture regime and local soil fertility. Thus, a better knowledge on plant responses to fertilization and moisture regime, at least, should be envisaged for the set up of commercial plantations.

Considering the importance of fruits with a standard pattern to make easy industrial processes such as husk removal and pulp recollection, an analysis of the mass of the fruits data was performed. We took the difference between the largest and smallest fruit of the entire sampled population and divided it by four, to make four different groups (Fig. 3). With that, we could check the predominant mass of fruits within each local. The smallest individual mass of fruits, $12.7 \mathrm{~g}$, was collected in $\mathrm{CO}$, while the largest one, $57.4 \mathrm{~g}$, was collected in SGO.

The predominant mass of fruits from CG, AQ and CO is situated within the 12.0-23.5 g per fruit group. In CO, they account for $90 \%$ of all fruits, indicating an almost homogeneity of small fruits. Fruits from SGO presented the largest mass, with $37.5 \%$ in the group 46.5-58.0 g. These fruit mass are bellow those observed for other areas of Brazil, such as found in Esmeralda, Minas Gerais State, an average mass around $66 \mathrm{~g}$ (Cetec, 1983). But they are not far from the $32.1 \mathrm{~g}$ average mass reported by Manfio et al. (2011), who evaluated samples from a broader area, encompassing the States of Mato Grosso do Sul, Minas Gerais, São Paulo, Pará, Maranhão e Pernambuco, representing the center-west, southeast, northeast and north regions of Brazil.

Fruits from SGO presented the largest dimensions and those from CO were the smaller ones (Table 1). On the hand, ratio between vertical and horizontal diameters of the entire is 1.06 for all sites, indicating an almost cylindrical shape. Such homogeneity of both fruits mass and dimensions makes easy the development of mechanical devices for industrial purposes.

There was not significant $(p>0.05)$ variations between proportion of husk and pulp to the whole macauba fruit (Table 1 ). However, there were significant effects $(p<0.05)$ of the biomes on fruit shell and kernel proportions. Fruits from the Cerrados showed a larger proportion of shell than fruits of the Pantanal, with the inverse proportion of kernels.

Husk and shell fractions are important because they can be used for the cogeneration of energy. The shell, especially, is particularly suitable for the production of activated coal. As demonstrated by Silva et al. (1986) shell coal has better performance than that made from eucalyptus tree, a traditional tropical coal-making hard wood. It is suitable for use in steel factories, as well as for domestic use.

Information on the correlation between biometric parameters and relative fractions of fruits are important for genetic breeding programs and for commercial cultivation. They can be useful to help finding materials with some desired characteristics. There no significant correlations between the number and total mass of fruits 
Table 1

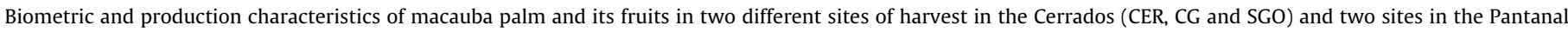
(PAN, CO and AQ) biomes.

\begin{tabular}{|c|c|c|c|c|c|c|c|c|}
\hline \multirow[t]{2}{*}{ Evaluated parameter } & \multicolumn{4}{|c|}{ Sites of harvest } & \multirow{2}{*}{$\begin{array}{l}\mathrm{CV}^{\mathrm{a}} \\
(\%) \\
\end{array}$} & \multicolumn{2}{|l|}{ Biomes } & \multirow{2}{*}{$\begin{array}{l}\text { CV } \\
(\%) \\
\end{array}$} \\
\hline & CG & SGO & $\mathrm{CO}$ & AQ & & CER & PAN & \\
\hline Stem circumference $(\mathrm{cm})$ & $\begin{array}{l}74.3 \mathrm{~b} \\
\pm 3.5^{\mathrm{b}}\end{array}$ & $\begin{array}{l}80.2 \mathrm{a}^{\mathrm{c}} \\
\pm 4.9\end{array}$ & $\begin{aligned} & 91.7 \mathrm{a} \\
\pm & 11\end{aligned}$ & $\begin{array}{c}69.7 \mathrm{~b} \\
\pm 3.20\end{array}$ & 24.5 & 77.3 & 80.7 & 26.5 \\
\hline Number of bunches per palm & $\begin{array}{l}5 \mathrm{a} \\
\pm 1.2\end{array}$ & $\begin{array}{l}2 \mathrm{~b} \\
\pm 1.2\end{array}$ & $\begin{array}{l}4 \mathrm{ab} \\
\pm 0.6\end{array}$ & $\begin{array}{l}3 \mathrm{~b} \\
\pm 0.7\end{array}$ & 64.9 & 3.8 & 3.7 & 72.3 \\
\hline Length of bunch (cm) & $\begin{array}{l}74 \mathrm{a} \\
\pm 4.2\end{array}$ & $\begin{array}{l}71 \mathrm{a} \\
\pm 3.6\end{array}$ & $\begin{array}{l}57 \mathrm{~b} \\
\pm 2.2\end{array}$ & $\begin{array}{l}77 \mathrm{a} \\
\pm 3.9\end{array}$ & 13.8 & 72.5 & 66.6 & 18.4 \\
\hline Mass of fruits per bunch (kg) & $\begin{array}{r}5.3 \\
\pm 0.7\end{array}$ & $\begin{array}{r}6.3 \\
\pm 1.0\end{array}$ & $\begin{array}{r}4.4 \\
\pm 0.4\end{array}$ & $\begin{array}{r}4.4 \\
\pm 0.4\end{array}$ & 40.9 & $5.8 \mathrm{~A}^{\mathrm{d}}$ & $4.4 \mathrm{~B}$ & 37.9 \\
\hline Number of fruits per bunch & $\begin{array}{r}194 \mathrm{~b} \\
\pm 37\end{array}$ & $\begin{array}{r}142 \mathrm{c} \\
\pm 22\end{array}$ & $\begin{array}{r}285 \mathrm{a} \\
\pm 30\end{array}$ & $\begin{array}{r}231 \mathrm{ab} \\
\pm 23\end{array}$ & 42.1 & $168 \mathrm{~B}$ & $258 \mathrm{~A}$ & 42.0 \\
\hline Total number of fruits per palm & $\begin{array}{l}970 \mathrm{a} \\
\pm 254\end{array}$ & $\begin{array}{r}320 \mathrm{~b} \\
\pm 80\end{array}$ & $\begin{array}{r}1080 \mathrm{a} \\
\pm 188\end{array}$ & $\begin{array}{r}765 \mathrm{ab} \\
\pm 171\end{array}$ & 66.3 & 645 & 923 & 78.9 \\
\hline Total mass of fruit per palm (kg) & $\begin{array}{r}25.5 \\
\pm 5.8\end{array}$ & $\begin{array}{r}13.7 \\
\pm 3.8\end{array}$ & $\begin{array}{r}16.4 \\
\pm 2.2\end{array}$ & $\begin{array}{r}15.8 \\
\pm 3.9\end{array}$ & 68.9 & 19.6 & 16.1 & 72.2 \\
\hline Fruits vertical diameter (mm) & $\begin{array}{l}36.5 \mathrm{~b} \\
\pm 1.2\end{array}$ & $\begin{array}{l}45.3 \mathrm{a} \\
\pm 1.4\end{array}$ & $\begin{array}{l}30.9 \mathrm{c} \\
\pm 0.8\end{array}$ & $\begin{array}{l}34.0 \text { bc } \\
\pm 1.0\end{array}$ & 9.1 & $38.6 \mathrm{~A}$ & $30.9 \mathrm{~B}$ & 14.8 \\
\hline Fruits horizontal diameter (mm) & $\begin{array}{l}34.6 \mathrm{~b} \\
\pm 1.1\end{array}$ & $\begin{array}{l}41.9 \mathrm{a} \\
\pm 1.4\end{array}$ & $\begin{array}{l}29.6 \mathrm{c} \\
\pm 0.7\end{array}$ & $\begin{aligned} & 31.6 \text { bc } \\
\pm & 0,9\end{aligned}$ & 8.6 & $36.1 \mathrm{~A}$ & $29.6 \mathrm{~B}$ & 14.3 \\
\hline Fruit epicarp (\%) & $\begin{array}{l}20.6 \\
\pm 1.0\end{array}$ & $\begin{array}{r}19.6 \\
\pm 0.6\end{array}$ & $\begin{array}{r}17.9 \\
\pm 0.7\end{array}$ & $\begin{array}{r}18.7 \\
\pm 0.6\end{array}$ & 12.6 & 19.6 & 17.9 & 12.6 \\
\hline Fruit mesocarp (\%) & $\begin{array}{r}47.9 \\
\pm 1.9\end{array}$ & $\begin{array}{r}44.8 \\
\pm 1.9\end{array}$ & $\begin{array}{l}51.2 \\
\pm 1.9\end{array}$ & $\begin{array}{l}48.1 \\
\pm 1.3\end{array}$ & 9.7 & 46.9 & 51.3 & 11.4 \\
\hline Fruit endocarp (\%) & $\begin{array}{l}26.6 \mathrm{~b} \\
\pm 1.4\end{array}$ & $\begin{array}{l}30.2 \mathrm{a} \\
\pm 1.8\end{array}$ & $\begin{array}{l}23.3 \mathrm{~b} \\
\pm 1.0\end{array}$ & $\begin{array}{l}27.9 \mathrm{ab} \\
\pm 1.1\end{array}$ & 14.3 & $28.2 \mathrm{~A}$ & $23.3 \mathrm{~B}$ & 15.3 \\
\hline Fruit kernel (\%) & $\begin{array}{r}4.9 \\
\pm 0.8\end{array}$ & $\begin{array}{r}5.4 \\
\pm 0.4\end{array}$ & $\begin{array}{r}6.7 \\
\pm 0.6\end{array}$ & $\begin{array}{r}5.3 \\
\pm 0.2\end{array}$ & 27.6 & $5.2 \mathrm{~B}$ & $6.7 \mathrm{~A}$ & 28.7 \\
\hline
\end{tabular}

a Coefficient of variation (\%).

b Mean \pm standard error of the mean.

c Different small letters within locals indicates they are statistically different $(p<0.05)$.

d Different capital letters on the average of biomes indicates they are statistically different $(p<0.05)$.

with the length of the bunch (Table 2). The total mass of fruits is associated to the number of fruits in all but AQ sites of harvests. Such relation suggests that increasing the number of fruits is a good way of increasing total fruit biomass production. Thus, finding a way to improve flower pollination and consequently to improve production.

One could expect that increasing the number of fruits the mass of individual fruits would decrease. This was true only for fruits from palms growing in $\mathrm{CO}$, as there is no significant correlation for the other sites. This indicates that it does not matter the size of the fruit, but the total number of fruits a palm produces. Also, the fractions of husk, pulp, shell and kernel are strongly related to the fruit mass. There is some exception to this pattern, as seen with the low correlation between fruit mass and kernel mass in CG and SGO, and the fruit mass with the shell mass in SGO.

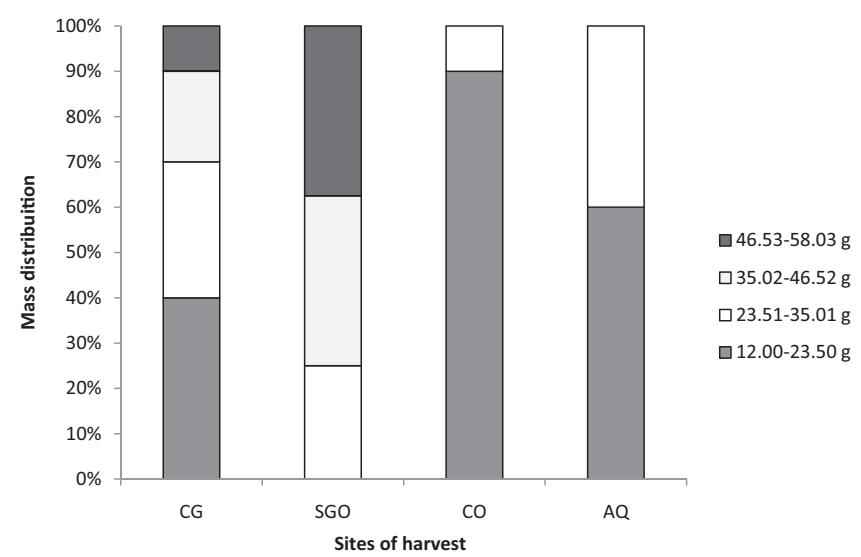

Fig. 3. Mass distribution of whole fruits of macauba in different sites of harvest of the Cerrados (CG and SGO) and Pantanal (CO and AQ) biomes.
High initial moisture contents were measured in fruits from all sites, varying from $49.1 \%$ in CG to $63.0 \%$ in CO (Fig. 4A). Other reports mention 34.3 and $53.0 \%$ pulp moisture contents at ripening stage (Silva et al., 2008; Ramos et al., 2008). Moisture contents of the kernel were more stable, varying from $17.1 \%$ (AQ) to 20.2 (SGO), but they are still higher than reports of $12.1 \%$ by Dessimoni-Pinto et al. (2010) and $6.5 \%$ by Hiane et al. (2006). It has to be considered that we made moisture determinations once the fruits were harvested, and we do not know if other reposts followed the same procedure.

The extraction of oil from pulp or kernel is hampered by high moisture contents, increasing the costs of the process. It also

Table 2

Pearson correlation between biometric parameters and relative fractions of macauba fruits in different locals of the Cerrados (CG and SGO) and Pantanal (CO and $\mathrm{AQ}$ ) biomes.

\begin{tabular}{|c|c|c|c|c|}
\hline Biometrics & CG & SGO & $\mathrm{CO}$ & AQ \\
\hline $\begin{array}{l}\text { Bunch length } \times \text { fruits } \\
\text { number }\end{array}$ & $0.41 \mathrm{~ns}^{\mathrm{a}}$ & $-0.06 \mathrm{~ns}$ & $-0.39 \mathrm{~ns}$ & $-0.54 \mathrm{~ns}$ \\
\hline $\begin{array}{l}\text { Bunch length } \times \text { total } \\
\text { fruit mass in the } \\
\text { bunch }\end{array}$ & $0.33 \mathrm{~ns}$ & $0.03 \mathrm{~ns}$ & $-0.09 \mathrm{~ns}$ & $0.28 \mathrm{~ns}$ \\
\hline $\begin{array}{l}\text { Fruits number in the } \\
\text { bunch } \times \text { total fruit } \\
\text { mass in the bunch }\end{array}$ & $\begin{array}{l}0.71 \\
p<0.002\end{array}$ & $\begin{array}{l}0.88 \\
p<0.004\end{array}$ & $\begin{array}{l}0.79 \\
p<0.007\end{array}$ & $0.52 \mathrm{~ns}$ \\
\hline $\begin{array}{l}\text { Fruits number in the } \\
\text { bunch } \times \text { fruit mass }\end{array}$ & $-0.48 \mathrm{~ns}$ & $0.03 \mathrm{~ns}$ & $\begin{array}{l}-0.67 \\
p<0.036\end{array}$ & $-0.61 \mathrm{~ns}$ \\
\hline Fruit mass $\times$ husk mass & $\begin{array}{l}0.94 \\
p<0.000\end{array}$ & $\begin{array}{l}0.84 \\
p<0.009\end{array}$ & $\begin{array}{l}0.94 \\
p<0.000\end{array}$ & $\begin{array}{l}0.95 \\
p<0.000\end{array}$ \\
\hline Fruit mass $\times$ pulp mass & $\begin{array}{l}0.99 \\
p<0.000\end{array}$ & $\begin{array}{l}0.93 \\
p<0.000\end{array}$ & $\begin{array}{l}0.98 \\
p<0.000\end{array}$ & $\begin{array}{l}0.95 \\
p<0.000\end{array}$ \\
\hline Fruit mass $\times$ shell mass & $\begin{array}{l}0.94 \\
p<0.000\end{array}$ & $0.68 \mathrm{~ns}$ & $\begin{array}{l}0.95 \\
p<0.000\end{array}$ & $\begin{array}{l}0.88 \\
p<0.000\end{array}$ \\
\hline $\begin{array}{l}\text { Fruit mass } \times \text { kernel } \\
\text { mass }\end{array}$ & $0.32 \mathrm{~ns}$ & $0.60 \mathrm{~ns}$ & $\begin{array}{l}0.66 \\
p<0.004\end{array}$ & $\begin{array}{l}0.85 \\
p<0.002\end{array}$ \\
\hline
\end{tabular}

a Not significant. 

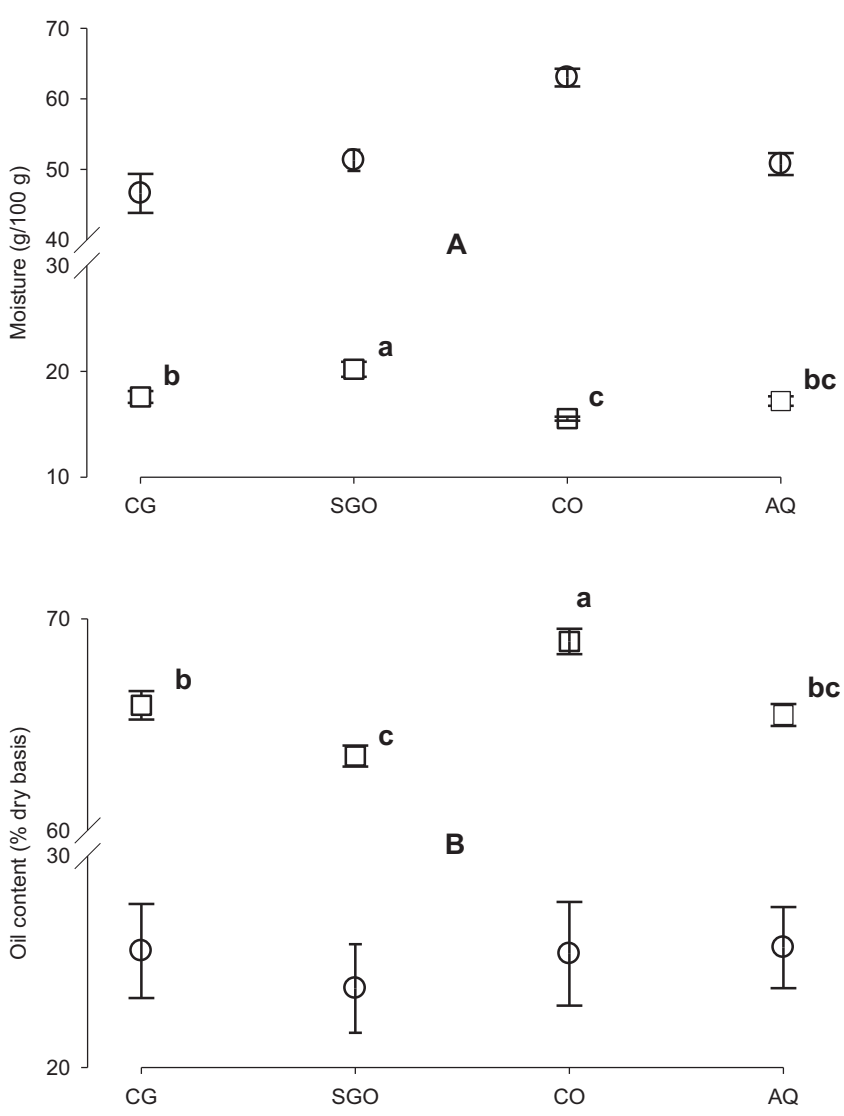

Fig. 4. Moisture (A) and oil content (B) of macauba fruits pulp ( $\bigcirc$ ) and kernel ( $\square$ ) in different sites of the Cerrados (CG and SGO) and Pantanal (CO and AQ) biomes. Bars are the standard error of the means. Averages followed by different letters are significantly different (Tukey, $p<0.05$ ).

allows easy growth of microorganisms and the deterioration due to physic-chemical reactions. Thus, for industrial extraction of oil a fast processing of the fruits is paramount, or fruits should be dried before storage for late processing.

Fruits from all sites showed similar pulp oil contents, with intrasite variability (Fig. 4B). Overall sampled population average was $25.1 \%$ on a dry basis. This is far lower than $55.9-69.9 \%$ reported for fruits from Minas Gerais State, in the southeast of the country (Cetec, 1983). However, there were differences for kernel oil content in the four sites. There was almost three times more oil in the kernel than in the pulp. The highest content was observed in CO (68.9\%) and the lowest in SGO (63.5\%). These values are higher than the 55.2-58.0\% reported by Cetec (1983), and close to what is seen for other known palm plants, like babassu palm (Orbignya phalerata), around 60.0\% (Machado et al., 2006).

Finding good correlation between fruits composition and morphology could be an important tool to select genotypes with interesting characteristics for agricultural production and industrial processing. Unfortunately, most relevant fruit characteristics are poorly correlated with oil contents either in the pulp or the kernel (Table 3). With that, it is almost impossible to infer pulp or kernel oil contents based on any measurable biometric fruit characteristic.

Thinking on commercial cultivation, we took individual plants production characteristics to estimate their theoretical yield of oil from the pulp and the kernel. Basic data for every one of the selected plants in each local was taken and estimated as if they were planted with two different row spacing, $5 \mathrm{~m} \times 2 \mathrm{~m}$, and $5 \mathrm{~m} \times 5 \mathrm{~m}$. This would result in a 1000 or 400 macauba palms per hectare, respectively. A thousand palms would result in a quite dense grove and probably would need intensive care and improved agronomic practices to be successful. On the other hand, 400 palms/ha would allow good light availability, mechanization practices or intercropping such as agrosilvipastoril systems.

If the average plants reported in this paper were cultivated in a system with 1000 palms per hectare, it would result in average total (pulp plus kernel) oil yield of $1470,909,1072$ and $1000 \mathrm{~kg}$ of oil/ha, respectively for CG, SGO, CO and AQ (Table 4). These values are far lower than those usually harbored by palm oil, for example, although better than other annual bearing-oil crops. With 400 palms/ha total oil yield would be even lower, but one has to consider that this production may be sustained for over 20 years of exploitation without further investment but minimal care, cleaning and some extra fertilization, and harvest.

On the other hand, giving the diversity observed within each local, the selection and multiplication of the best palms could result in far improved oil yield. Palm number six from CG, for example, may provide population able to produce around $4000 \mathrm{~kg}$ of $\mathrm{oil} / \mathrm{ha}$ in a $1000 \mathrm{palms} / \mathrm{ha}$. These estimates are purely hypothetical, are there is not yet reports on the behavior of the macauba palm under controlled cultivation, or in different plant densities and under good agronomic management. Also, the efficiency of industrial procedures to extract oil from the pulp and kernel still needs improvements, as only around $70 \%$ of the total oil content is extracted so far with the known procedures.

Comparing sites, palms from CG presented higher productivity of fruits/ha than the other sites, almost twice as produced in SGO (Fig. 5). Bigger fruits from SGO (Table 2) did not result in high yield. There was also bigger pulp oil production in CG than any other site. On the other hand, kernel oil yield from GC and CO were similar, because of the higher kernel oil content of fruits from CO (Fig. 4B).

The use of coproducts is essential for the energetic and economic balance in the industrial point of view. The husk and the shell can be used for cogeneration of energy. Shell has got caloric power equals to $5152 \mathrm{kcal} / \mathrm{kg}$ (Vilas Boas et al., 2010), which is higher than eucalyptus ( 4486 to $4641 \mathrm{kcal} / \mathrm{kg}$, according to Lemenih and Bekele, 2004). Shell density is $1.29 \mathrm{~g} / \mathrm{cm}^{3}$ (Vilas Boas et al., 2010), also higher than eucalyptus $\left(0.85 \mathrm{~g} / \mathrm{cm}^{3}\right.$, according to Rodrigues and Rousset, 2009).

Other coproducts of importance are the cakes remaining from the pulp and the kernel (Fig. 5). There is no other limitation to use these cakes as animal or human feedstock but the residual oil content, because they do not present any known toxic or antinutritional compounds. Thus, improving oil extraction efficiency will result in

Table 3

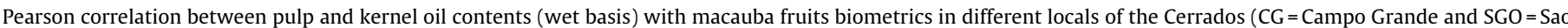
Gabriel do Oeste $)$ and Pantanal ( $\mathrm{CO}=$ Corumba and $\mathrm{AQ}=$ Aquidauana $)$ biomes.

\begin{tabular}{|c|c|c|c|c|c|c|}
\hline Oil content & & Biometrics & CG & SGO & $\mathrm{CO}$ & $\mathrm{AQ}$ \\
\hline Pulp & $\times$ & Fruit mass & $0.4 \mathrm{~ns}^{\mathrm{a}}$ & $0.25 \mathrm{~ns}$ & $-0.20 \mathrm{~ns}$ & $0.23 \mathrm{~ns}$ \\
\hline Kernel & $x$ & Fruit mass & $-0.26 \mathrm{~ns}$ & $0.00 \mathrm{~ns}$ & $-0.41 \mathrm{~ns}$ & $0.65 p<0.004$ \\
\hline Pulp & $x$ & Mesocarp mass & $0.39 \mathrm{~ns}$ & $0.20 \mathrm{~ns}$ & $-0.08 \mathrm{~ns}$ & 0.17 \\
\hline Kernel & $x$ & Kernel mass & $0.05 \mathrm{~ns}$ & $0.36 \mathrm{~ns}$ & $0.25 \mathrm{~ns}$ & $0.39 \mathrm{~ns}$ \\
\hline
\end{tabular}

\footnotetext{
a Not significant.
} 
Table 4

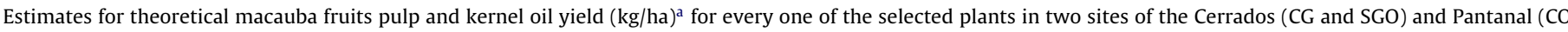
and $\mathrm{AQ}$ ) biomes, in two different plants densities (1000 or $400 \mathrm{palms} / \mathrm{ha}$ ).

\begin{tabular}{|c|c|c|c|c|c|c|c|c|c|}
\hline \multirow[t]{2}{*}{ Palm } & \multicolumn{2}{|c|}{1000 Palms } & \multicolumn{2}{|c|}{400 Palms } & \multirow[t]{2}{*}{ Palm } & \multicolumn{2}{|c|}{1000 Palms } & \multicolumn{2}{|c|}{400 Palms } \\
\hline & Pulp & Kernel & Pulp & Kernel & & Pulp & Kernel & Pulp & Kernel \\
\hline CG & & & & & SGO & & & & \\
\hline 1 & 1326 & 530 & 368 & 147 & 1 & 220 & 88 & 75 & 30 \\
\hline 2 & 1528 & 611 & 225 & 90 & 2 & 319 & 128 & 195 & 78 \\
\hline 3 & 119 & 48 & 246 & 99 & 3 & 527 & 211 & 452 & 181 \\
\hline 4 & 1092 & 437 & 1049 & 420 & 4 & 280 & 112 & 73 & 29 \\
\hline 5 & 1164 & 466 & 605 & 242 & 5 & 460 & 184 & 205 & 82 \\
\hline 6 & 2788 & 1115 & 682 & 273 & 6 & 436 & 174 & 311 & 125 \\
\hline 7 & 615 & 246 & 273 & 109 & 7 & 981 & 392 & 644 & 258 \\
\hline 8 & 2374 & 949 & 658 & 263 & 8 & 227 & 91 & 179 & 72 \\
\hline 9 & 378 & 151 & 86 & 34 & $\mathrm{ND}^{\mathrm{b}}$ & ND & ND & ND & ND \\
\hline 10 & 212 & 85 & 90 & 36 & ND & ND & ND & ND & ND \\
\hline CO & & & & & $A Q$ & & & & \\
\hline 1 & 644 & 258 & 299 & 120 & 1 & 173 & 69 & 106 & 42 \\
\hline 2 & 536 & 215 & 376 & 150 & 2 & 116 & 46 & 50 & 20 \\
\hline 3 & 142 & 57 & 240 & 96 & 3 & 625 & 250 & 425 & 170 \\
\hline 4 & 1573 & 629 & 817 & 327 & 4 & 1425 & 570 & 544 & 218 \\
\hline 5 & 165 & 66 & 195 & 78 & 5 & 72 & 29 & 79 & 31 \\
\hline 6 & 1063 & 425 & 442 & 177 & 6 & 1012 & 405 & 395 & 158 \\
\hline 7 & 586 & 234 & 626 & 250 & 7 & 782 & 313 & 315 & 126 \\
\hline 8 & 855 & 342 & 337 & 135 & 8 & 1510 & 604 & 718 & 287 \\
\hline 9 & 180 & 72 & 419 & 168 & 9 & 951 & 381 & 342 & 137 \\
\hline 10 & 531 & 212 & 693 & 277 & 10 & 264 & 106 & 92 & 37 \\
\hline
\end{tabular}

a Considering $70 \%$ oil extraction efficiency.

b Not determined.
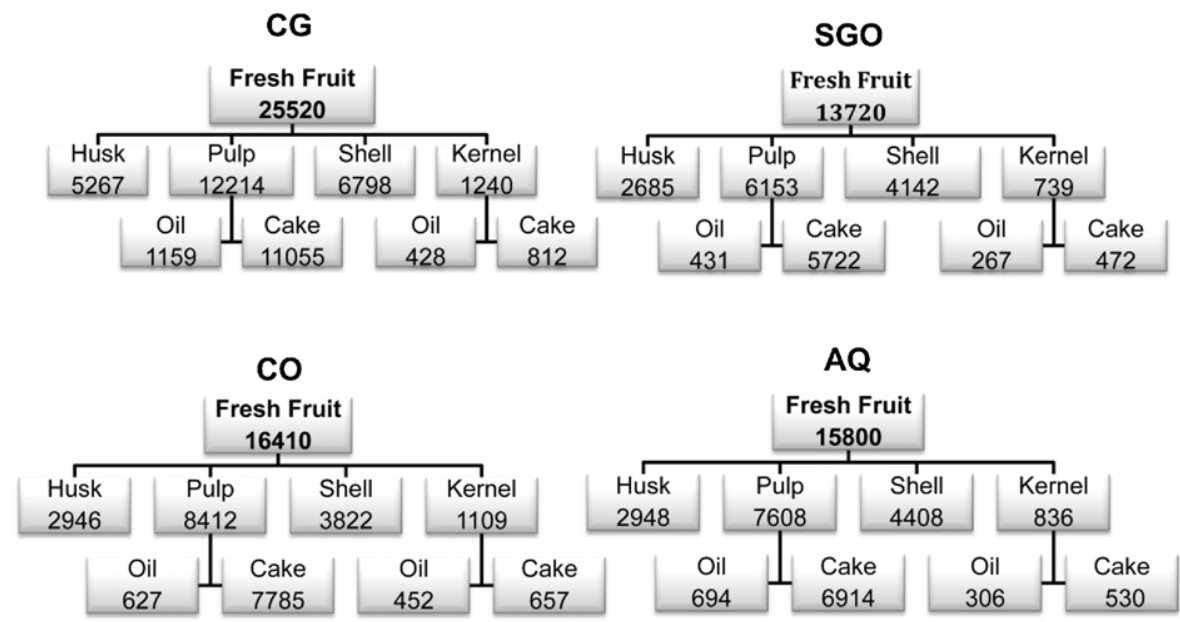

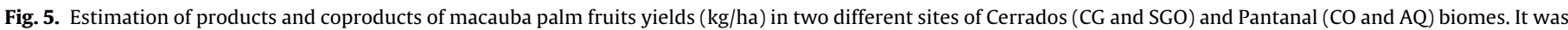
considered production of 1000 palms/ha, and $70 \%$ oil recovery efficiency using mechanical extraction.

cake of better quality. Pulp cake shows high fiber's contents, around $42 \%$, but protein contents around $8.5 \%$. Kernel cake fiber content is $34 \%$ but has got more than $50 \%$ protein content (Cetec, 1983). Cake production of fruits from CG, for example, around 12 ton, could be a reliable extra source of income, adding to what could be earned with the oil yield. These different characteristics within plants from all sites indicate that they could be a useful reserve of genetic materials for further development, not only for oil but for other products.

\section{Conclusion}

It was observed large variation in biometrics, biomass production potential and oil yield in native macauba palms from representative sites of the Brazilian Cerrados and Pantanal biomes. However, fruits biometric features did not correlate with oil contents. Also, oil contents of fruits from all sites are almost a half of that from other important native macauba's groves areas of Brazil.
On average, plants from CG showed better general productive characteristics than any other of the studied sites, but a large variability in fruits size, which may demand previous classification of fruits for industrial processing purposes. Palms from CO presented smaller fruits, but they were more homogeneous in size and with higher kernel oil contents. Fruits from SGO show bigger mass and size, but it did not result in higher biomass production or oil yield.

Results could help the planning for a more rational exploitation of native macauba groves in these areas. On the other hand, they indicate that the evaluated materials would not be the most indicated for improved cultivation systems in which the main objective is oil yield.

\section{References}

Amaral, F.P.do., Broetto, F., Batistella, C.B., Jorge, S.M.A., 2011. Extração e caracterização qualitativa do óleo da polpa e amêndoas de frutos de macauba 
[Acrocomia aculeata (Jacq) Lood ex. Mart] coletadas na região de Botucatu, SP. Rev. Energia Agric. 26, 12-20.

AOAC, 2005. Official Methods of Analysis of the Association Analytical Chemists, vol. 18, Gaithersburg, MD.

Basiron, Y., 2005. Palm oil. In: Shahidi, F. (Ed.), Bailey's Industrial Oil and Fat Products. 6 th ed. Wiley-Interscience, New York, pp. 333-429.

Cetec. Centro Tecnológico de Minas Gerais, 1983. Produção de combustíveis líquidos a partir de óleos vegetais: Estudo das oleaginosas nativas de Minas Gerais (Biofuels Production From Vegetable Oils: Study of Native Oleaginous Plants From Minas Gerais), Belo Horizonte, MG, 152 pp.

Dessimoni-Pinto, N.A.V., Silva, V.M.da, Batista, A.G., Vieira, G., Souza, C.R.de, Dumont P.V., Santos, G.K.M.dos, 2010. Características físico-químicas da amêndoa de macauba e seu aproveitamento na elaboração de barras de cereais. Alimentação e Nutrição 21, 77-84.

Hiane, P.A., Ramos Filho, M.M., Ramos, M.I.L., Macedo, M.L.R., 2005. Bocaiuva, Acrocomia aculeata (Jacq.) Lodd, pulp and kernel oils: characterization and fatty acid composition. Braz. J. Food Technol. 8, 256-259.

Hiane, P.A., Baldasso, P.A., Marangoni, S., Macedo, M.L.R., 2006. Chemical and nutritional evaluation of kernels of bocaiuva, Acrocomia aculeata (Jacq.) Lood. Ciência e Tecnologia de Alimentos 26, 683-689.

Klink, C.A., Machado, R.B., 2005. Conservation of the Brazilian Cerrado. Conserv. Biol. 19, 707-713.

Lemenih, M., Bekele, T., 2004. Effect of age on calorific value and some mechanical properties of three eucalyptus species grown in Ethiopia. Biomass Bioenergy 27, 223-232.

Machado, G.C., Chaves, J.B., Antoniassi, R., 2006. Composição em Ácidos Graxos e Caracterização Física e Química de óleos de babaçu. Ceres 53, 463-470.
Manfio, C.E., Motoike, S.Y., Santos, C.E.M., Pimentel, L.D., Queiroz, V., Sato, A.Y., 2011 Repetibilidade em características biométricas do fruto de macauba. Ciência Rural $41,70-76$.

Poetsch, J., Lewandowski, D.H.I., Oberländer, D., Hilger, T., 2012. Acrocomia aculeata-a sustainable oil crop. Rural 21 (3), 41-44.

Ramos, M.I.L., Siqueira, E.M.A., Isomura, C.C., Barbosa, A.M.J., Arruda, S.F., 2007. Bocaiuva (Acrocomia aculeata (Jacq.) Lood) improved vitamin A status in rats. J. Agric. Food Chem. 22, 3186-3190.

Ramos, M.I.L., Ramos Filho, M.M., Hiane, P.A., Braga Neto, J.A., Siqueira, E.M.A., 2008 Qualidade nutricional da polpa de bocaiuv Acrocomia aculeata (Jacq.) Lodd. Ciência e Tecnologia dos Alimentos 28, 90-94.

Rodrigues, T.O., Rousset, P.L.A., 2009. Effects of torrefaction on energy properties o Eucaliptus grandis wood. Cerne 15, 446-452.

Roscoe, R., Richetti, A., Maranho, E., 2007. Análise de viabilidade técnica de oleaginosas para produção de biodiesel em Mato Grosso do Sul. Revista Política Agrícola 16, 48-59.

Schessil, M., 1999. Floristic composition and structure of floodplain vegetation in the northern Pantanal of Mato Grosso Brazil. Phyton 39, 303-336.

Silva, J.C., Barrichelo, L.E.G., Brito, J.O., 1986. Endocarpos de babaçu e de macauba comparados a madeira de Eucalyptus grandis para a produção de carvão vegetal. IPEF 34, 31-34.

Silva, M.R., Lacerda, D.B.C.L., Santos, G.G., Martins, D.M.O., 2008. Caracterização química de frutos nativos do Cerrado. Ciência Rural 38, 1790-1793.

Vilas Boas, M.A., Carneiro, A.C.O., Vital, B.R., Carvalho, A.M.M.L., Martins, M.A., 2010 Efeito da temperatura de carbonização e dos resíduos de macauba na produção de carvão vegetal. Scientia Florestalis 38, 481-490. 